\title{
Bazı Tarımsal Girdilere Uygulanan Katma Değer Vergisi (KDV) İndiriminin Üreticiler Açısından Değerlendirilmesi
}

\section{Ferit ÇOBANOĞLU ${ }^{1}(\mathbb{D})$, Halil ibrahim YILMAZ ${ }^{* 1}$, Sıdıka BOZKIRAN ${ }^{1}\left(\mathbb{D}\right.$, Yeşim ÖZTÜRK $^{1}(\mathbb{D})$}

\author{
${ }^{1}$ Aydın Adnan Menderes Üniversitesi, Ziraat Fakültesi, Tarım Ekonomisi Bölümü, Aydın
}

Öz: Bu çalışmada, tarımsal üretimin iki temel girdisi olan gübre ve yemde, 2016 yılında uygulanmaya başlanmış olan KDV istisnası uygulamasının, bu girdi fiyatlarıın, 2015=100 bazlı endekse göre değişiminin belirlenmesi ve Aydın ilindeki üreticiler açısından değerlendirilmesini ortaya koymak amaçlanmıştır. Öncelikle, Türkiye i̇statistik Kurumu (Tüik) tarafından hazırlanıp, belirli dönemlerde kullanıma sunulan 2015=100 bazlı tarımsal girdi fiyat endeksi hesaplanmasında kullanılan gübre ve yem girdi kalemleri incelenmiştir. Projede kullanılan diğer veriler, anket çalışmasından elde edilmiştir. Aydın'ın tarımsal üretim potansiyeli oldukça yüksek olan Germencik, İncirliova ve Koçarlı ilçelerindeki üreticiler, araştırma popülasyonunu (evrenini) oluşturmuştur. Örneklemin belirlenmesinde rassal olmayan örnekleme yöntemlerinden, amaçlı (kasti) örnekleme yöntemi kullanılmışır. Buna yönelik olarak, yukarıda belirtilmiş olan ilçelerde, 50 adet üretici ile anket çalışması yapılmıştır. Gübre ve hayvan yemi fiyatlar genel düzeyinde, 2020 yılında, 2015 yılı baz dönemine göre \%60-70'lere varan düzeyde önemli artışların olduğu belirlenmiştir. 2018 yılı ortasından itibaren, gübre fiyatları genel düzeyinde önemli artışların olduğu belirlenmiştir. Hayvan yemi fiyat seviyelerinde ise 2016 yılından itibaren, belirli düzeyde artışların olduğu belirlenmiştir. Bu sebeple, KDV istisnasının hayvan yemi fiyat düzeylerinde önemli etkisinin olmadığı düşünülmektedir. Üreticilerin özellikle gübre, ilaç, motorin ve elektrikte uygulanmakta olan vergi, özellikle KDV oranları hakkında yeterince bilgi düzeyine sahip oldukları belirlenmiştir.

Anahtar kelimeler: Hayvan yemi, gübre, vergi istisnası, girdi fiyatı, endeks

\section{Evaluation of Value Added Tax (VAT) Reduction Applied to Some Agricultural Inputs from the Perspective of Producers}

\begin{abstract}
In the present study, it was aimed to reveal the VAT exemption application, which started to be applied in 2016 in fertilizers and feed, which are two main inputs in agricultural production, the change of these input prices according to the index based on $2015=100$ and the evaluation of the producers in Aydın province. First, Turkey Statistical Institute (TSI) prepared by, made available during a certain period 2015 = 100 base, agricultural input price index used to calculate fertilizer and feed inputs items were examined. Other data used in the project were obtained from the survey study. Producers in Germencik, Incirliova and Koçarlı districts, which have a very high agricultural production potential in Aydin, formed the research population (universe). Judgmental sampling method, one of the non-random sampling methods, was used in determining the sample. For this purpose, a survey was conducted with 50 producers in the districts mentioned above. In the general level of fertilizer and animal feed prices, it has been determined that there are significant increases up to $60-70 \%$ in 2020 compared to the base period of 2015. Since mid 2018, it has been determined that there have been significant increases in the overall level of fertilizer prices. It has been determined that there has been a certain increase in animal feed price levels since 2016. Therefore, it is considered that the VAT exemption does not have a significant effect on animal feed price levels. It has been determined that the producers have sufficient knowledge about the taxes, especially VAT rates, which are applied on fertilizers, agricultural pesticides, diesel and electricity.
\end{abstract}

Keywords: Animal feed, fertilizer, tax exemption, input price, index

\section{Giriş}

Bitkisel üretim için gübre ve hayvansal üretim için yem en önemli girdi kalemlerini oluşturmaktadır. Ürünlere, yetiştirme koşullarına, ekolojiye, sahip olunan teknoloji ve üretici özelliklerine göre değişmekle birlikte, Türkiye'de toplam tarımsal girdiler içerisinde gübrenin \%15-20 düzeyinde payı bulunmaktadır. Bununla birlikte, gübrenin bilinçli kullanımı ile bitkisel üretimin \%50-75 oranında artış gösterebileceği bazı ürünlerde bu oranın \%100'e çıkabileceği ifade edilmektedir (Gezgin, 2015).

Dünya genelinde 2015 yılında hektar başına ortalama 137.61 kg gübre kullanılırken, Türkiye'de aynı yılda hektar başına ortalama $106.67 \mathrm{~kg}$ gübre kullanılmaktadır. Bunun yanında aynı yıl Hollanda $258.15 \mathrm{~kg}$, İsrail $240.24 \mathrm{~kg}, \mathrm{ABD}$ 137.03 kg, Avrupa Birliği ortalaması 157.19 kg düzeyindedir
(Anonim, 2021). Yemlerin, hayvansal üretimde işletme girdi maliyetlerinin \%50-70'ini oluşturduğu ve bu sebeple hayvancılık sektörünün gelişiminde önemli bir paya sahip olduğu ifade edilebilir (Şekerdil ve Engindeniz, 2020). Karma yem sanayii, hububatlar, yağlı tohumlar gibi bitkisel üretimden elde edilen, değirmencilik, nişastacılık, şeker yan ürünleri, yağlı tohum küspeleri gibi gıda sanayinden üretilen ürünleri, hayvan ihtiyaçlarına göre işleyip vitamin, mineral

*Sorumlu Yazar: halil.yilmaz@adu.edu.tr. Bu çalışma Aydın Adnan Menderes Üniversitesi Bilimsel Araştırma Projeleri Koordinasyon Birimi tarafından desteklenmiştir (Proje No: ZRF-17050)

Geliş Tarihi: 4 Ocak 2021

Kabul Tarihi: 8 Haziran 2021 
ve premiksler ile sentezleyerek en uygun formda ve maliyette hayvancılığın kullanımına sunan bir endüstridir (Akbay ve Ak, 2018).

Bitkisel üretimde gübre (Bayramoğlu ve ark., 2021) hayvansal üretimde ise yem girdilerinin (Sıkar ve Çimrin, 2020) en önemli maliyet kalemlerini oluşturduğu ifade edilebilir. Gübre ve yem fiyatlarının olabildiğince makul bir seviyede olmasının, üreticilerin tarımsal üretimde rekabet edebilirliğinin sağlanması ve sürdürülebilirlik açısından oldukça önemli olduğu düşünülmektedir (Kara ve Eroğlu, 2018).

Harmanşah (2018) gübre sektöründeki gelişmeleri, özellikle gübre fiyatlarındaki Katma Değer Vergisi (KDV) oranının istisna tutulmasından sonraki süreçte analiz etmiştir. Gübrenin, bitkisel üretim maliyetlerindeki payının her ne kadar \%15-20 düzeyinde olsa da, bilinçli kullanıldığında \%50'den fazla verim artışı sağlayabildiği ifade edilmiştir. Tarımda kullanılan gübrelerin ana hatları ile doğal gübreler (ahır gübresi, kompost gübre, yeşil gübre, solucan gübresi) ve yapay gübreler (azotlu gübreler, potasyumlu gübreler, fosfatlı gübrele, özel formulasyonlar ve kompoze gübreler) olarak ikiye ayrılır (Ilgar, 2020). Ülkemizde fiziki olarak yıllık ortalama 5-6 milyon ton dolayında kimyevi gübre kullanılmakta olduğu belirtilmektedir (Anonim, 2018a). Türkiye'nin gerek kimyevi gübre, gerekse de kimyevi gübrelerin hammaddesi açısından dışa bağımlı olduğu ifade edilmektedir (Şahin, 2016).

Harmanşah (2019) tarafından, 2016 yılının, KDV'nin sıfırlanmasından dolayı, gübre tüketiminin en fazla olduğu dönem olarak belirtilmiştir. Hektar başına saf madde olarak gübre tüketiminin $138 \mathrm{~kg}$ olup, dünya ortalamaları düzeyinde olduğu ifade edilmiştir. Çalışmada gübre fiyatını etkileyen faktörler de incelenmeye çalışılmıştır. Buna göre, dünya genelinde gübre ticaretinin, gerek hammadde, gerekse mamul gübre olsun, dolar üzerinden yapıldığı belirtilmektedir. Gübre fiyatlarını etkileyen faktörlerin başında dolar kurundaki değişmelerin geldiği ifade edilmiştir. Esas olarak dünya gübre piyasasındaki fiyatları; konjonktürel gelişmeler ve arz talep dengesi gibi faktörlerin etkilediği vurgulanmıştır. Ülkemizde de gübre sektöründe yoğun bir rekabetin yaşanmakta olduğu bildirilmektedir. Kimyevi gübre üretimi, tüketimi ve ithalatı arasındaki ilişkinin; gübre fiyatı, çiftçinin alım gücü ve devletin yaptığı destekleme miktarı ve ürün deseni ile açıklanabileceği belirtilmektedir.

Yem ve gübrede KDV'nin kaldırılmasını da kapsayan "Gelir Vergisi Kanunu ile Bazı Kanunlarda Değişiklik Yapılmasına Dair Kanun Tasarısı", Türkiye Büyük Millet Meclisi (TBMM) Genel Kurulu'nda kabul edilerek yasalaştığı belirtilmektedir. Tasarının, TBMM'ne sunulan genel gerekçesinde, tarım ve hayvancılığın desteklenmesine yönelik, yemde ve gübrede 104
KDV'nin kaldırılması gerektiği ifade edilmiştir. Bakanlar Kurulu tarafindan 5 Ocak 2016 tarihinde TBMM Başkanlığına sunulan "Gelir Vergisi Kanunu ile Bazı Kanunlarda Değişiklik Yapılmasına Dair Kanun Tasarısı" ile 25/10/1984 tarihli ve 3065 sayılı KDV Kanununun 13. Maddesinde değişikliğe gidilmiştir. Bu değişiklik ile gübre ve yem teslimleri KDV istisnası kapsamında değerlendirilerek, oranın sıfırlanmış olduğu ifade edilmiştir (Anonim, 2018b). Gübre sektöründe hammadde maliyetinin, büyük oranda ithalata bağımlı olunduğu vurgulanmıştır. Bu sebeple, fiyatlar genel düzeyinin yüksek olduğu ifade edilmiştir. Üretim maliyetlerinde hammaddenin payının \%65-80' arasında değiştiği vurgulanmıştır. Bu hammaddelerin esas olarak doğalgaz, fosfat kayası, amonyak, sülfürik asit, nitrik asit ve fosforik asit olduğu belirtilmiştir. Tarımsal üretim ve dolayısıyla maliyetinde önemli bir payı oluşturan gübre girdisinin, toplam maliyet içindeki payının azaltılması amacıyla, gübrede 2016 yılında KDV oranının sıfırlanmış olduğu ifade edilmiştir. Ayrıca dünyada yaşanan fiyat artışları ve oynaklıklarından çiftçiyi korumak amacıyla, 2003 yılının son çeyrek döneminden itibaren, alan bazlı ürün grubuna göre değişen miktarlarda, Çiftçi Kayıt Sistemi (ÇKS)'ne kayıtlı olmak koşulu ile çiftçilere, tarımsal desteklemeler yapılmaya başlandığı belirtilmiştir (Anonim, 2018c).

Demir (2016) tarımsal üretimde en önemli girdi kalemlerinden olduğu kabul edilen gübre ve yem teslimlerinin, 2016 yılında istisna kapsamına alındığını belirtmiştir. Bu istisnanın başlıca amaçlarının şunlar olduğu ifade edilmiştir: (i) Bitkisel ve hayvansal üretim faaliyetinde bulunan üreticilerin ödemesi gereken vergi yükünün ve üretim maliyetlerinin düşürülmesi, (ii) Böylelikle üreticilerin teşvik edilerek, tarımsal üretimin arttırılması, (iii) Tarımsal (bitkisel ve hayvansal) ürün ihracatının geliştirilip, ithalatının azaltılması. Bu amaçların gerçekleştirilebilmesi için "6663 sayılı Gelir Vergisi ile Bazı Kanunlarda Değişiklik Yapılmasına Dair Kanun ile Katma Değer Vergisi (KDV) Kanunu'nun 13'üncü maddesine (I) bendi eklenmiş olup, söz konusu bent kapsamında Gıda, Tarım ve Hayvancılık Bakanlığı tarafından tescil edilmiş gübrelerin ve bu gübrelerin hammaddelerinin gübre üreticilerine tesliminde ve yine aynı bentte sayılı yemlerin teslimlerine KDV istisnası getirildiği" belirtilmiştir. Söz konusu KDV istisnasının tam istisna olduğu vurgulanmıştır. Bu istisnadan dolayı söz konusu olan KDV iadesinin, mükelleflerin tescil edilmiş gübreleri ile bu gübrelerin hammaddelerini ve yasal kapsam içerisinde yer alan yemleri, teslim aldığı tarihe göre, ya tam istisnanın sağladığı iade yaklaşımlarına göre, ya da indirimli oranın sağladığı iade usullerine göre, yükümlülerce isteneceği ifadelerine değinilmiştir. KDV istisnası, tam istisna kapsamında yer aldığı için, yükümlülerin söz konusu 
malların tesliminde KDV almayacağı vurgulanmıştır. Buna göre, mükellefler kendilerine yapılan mal veya hizmet teslimlerinde, söz konusu KDV tutarını, kendilerine ait mal veya hizmetlerden alınan KDV tutarından indirecekler, indirim yöntemi ile giderilemeyen KDV olması durumunda ise istisna kapsamında söz konusu olan KDV'yi nakden veya mahsuben iade alabilecekleri belirtilmiştir.

Gübre ve yemlerde söz konusu olan KDV istisnasının, tarımsal üretim ekosisteminde, üreticilerin rekabet edebilirliğini geliştirerek, sürdürülebilirliğin sağlanmasına yönelik olarak, önemli yapı taşlarından birini yerine getirdiğini vurgulamıştır. Böylelikle, kaliteli ve yeterli miktarda gübre ve yemin üreticiler tarafından daha kolay ulaşılabileceği belirtilmiştir (Anonim, 2016).

Yalçınkaya ve Aktaş (2019) yemde uygulanan KDV oran indiriminin, doğrudan yem fiyatlarına, dolaylı olarak da et ve süt fiyatlarına olan etkisini araştırmışlardır. KDV oran indirimlerinin etkisi, uzun dönemde Johansen Eşbütünleşme Analizi ve kısa dönemde Granger Nedensellik Analizi ile test edilmiştir. Analizler sonucunda, KDV oran indirimlerinin kısa ve uzun dönemde yem, et ve süt fiyatlarına etki etmediği tespit edilmiştir. Yapılan yorumlamada; ürün fiyatlarının oluşumunda en önemli sebebin, piyasa yapısının kendisi olduğu ve bu yapı içerisinde özellikle ürünlerin arz ve talep esnekliklerinin en önemli sebepler olduğu ifade edilmiştir. Sadece vergi politikalarının ise ürün fiyatlarının düşürülmesinde yeterli olmadığı, buna karşın vergi indirimlerine bağlı olarak devletin ihtiyaç duyduğu fonlarda da azalmaların görülebileceği vurgulanmıştır. Sonuç olarak, yem fiyatlarındaki KDV oranı indiriminin, beklenildiği gibi et ve süt fiyatlarına yansımadığı belirtilmiştir. Bu çıkarımlara bağlı olarak, et ve süt fiyatları üzerinde tahmin edilen olası indirimlerin meydana gelmesi için, piyasa şartlarında, özellikle arz ve talep cephesinde değişikliklerin olması gerektiği vurgulanmıştır.

$\mathrm{Bu}$ çalışmada, tarımsal üretimde oldukça önemli iki girdi olan gübre ve yemde, 2016 yılında uygulanmaya başlanmış olan KDV istisnası uygulamasının, söz konusu girdi fiyatlarının, 2015=100 bazlı tarımsal girdi fiyat endeksine göre değişimini ve Aydın ilindeki üreticiler açısından değerlendirilmesini ortaya koymak amaçlanmıştır. Yapılan literatür taramalarına göre, 2016 yılı ve sonrasında, bu girdi fiyatlarındaki değişimleri belirleyen ve özellikle söz konusu girdilerdeki KDV istisnasının üreticiler açısından değerlendirilmesini ortaya koyan detaylı bir çalışma yapılmadığı belirlenmiştir. Buna yönelik olarak yapılan proje çalışmasında, giriş bölümünden sonra, yürürlüğe girmiş olan KDV istinası uygulaması özet olarak incelenmiştir.

\section{Gübre ve yem teslimlerinde KDV iadesi}

6663 sayılı Kanun ile gelen yeni düzenleme özet olarak şu konuları incelemektedir. "Bu yasal düzenleme ile gübre ve yem ticaretinde, gübre üreticileri/ithalatçısı veya
ÇOBANOĞLU F, YILMAZ HI, BOZKIRAN S, ÖZTÜRK Y satıcılarının Tarım ve Hayvancılık Bakanlığı tarafından tescil edilmiş gübrelerini satmaları durumunda, tam istisna kapsamında KDV tahsil etmeyeceklerdir. Türk Gümrük Tarife Cetvelinin 2303.10 tarife pozisyon numarasında sınıflandırılan nişastacılık artıkları ve benzeri artıklar ile 2303.30.00.00.00 gümrük tarife istatistik pozisyon numarasında sınıflandırılan biracılık ve damıtık içki sanayinin posa ve artıkları hariç, tam yağlı soya (fullfat), kepek, razmol, balık unu, et unu, kemik unu, kan unu, tapyoka (manyok), sorgum ve her türlü fenni karma yemler (kedi-köpek mamaları hariç), saman, yem şalgamı, hayvan pancarı, kök yemler, kuru ot, yonca, fiğ, korunga, hasıl ve slajlık mısır, üçgül, yemlik lahana, yem bezelyesi ve benzeri hayvan yemleri (yeşil ve kuru kaba yemler ve bunların pellet şeklinde veya mevsimsel ihtiyaçlara göre bir bağlayıcı kullanılarak veya kullanılmadan işlem görmüş olanları dahil) indirimli orandan kaynaklanan KDV iadesi sağlanmaktadır" (Demir, 2016).

\section{MATERYAL VE YÖNTEM}

\section{Materyal}

Öncelikle, Türkiye İstatistik Kurumu (TÜiK) tarafından hazırlanıp, belirli dönemlerde kullanıma sunulan 2015=100 bazlı, tarımsal girdi fiyat endeksi hesaplanmasında kullanılan gübre ve yem girdi kalemleri incelenmiştir (TüiK, 2020). Projede kullanılan diğer veriler, Aydın ilinde, gübre ve yemde uygulanan KDV indirimine ilişkin göreli olarak yeterli bilgi sahibi olduğu öngörülen üreticiler ile yüz-yüze yapılan anket çalışmasından elde edilmiştir. Bunun için Aydın'ın tarımsal üretim potansiyeli oldukça yüksek olan Germencik, Incirliova ve Koçarlı ilçelerindeki üreticiler, araştırma popülasyonunu (evrenini) oluşturmuştur. Örneklemin belirlenmesinde rassal olmayan örnekleme yöntemlerinden, amaçlı (kasti) örnekleme yöntemi kullanılmıştır. Amaçlı örnekleme yönteminde, örnekleme dahil edilecek birimleri, araştırmacı önceki bilgi, deneyim ve gözlemlerinden hareketle, araştırmanın amacına uygun olarak kendi yargısıyla belirler. Araştırmacı kendi yargı ve değerlendirmeleriyle hareket ettiği için evren hakkında fikir sahibi olmalıdır (Ural ve Kılıç, 2011). Bu proje çalışmasında ise, tarımsal üretimde kullanılmakta olan en önemli girdiler olan gübre ve yemde söz konusu olan KDV istisnası hakkında yeterli bilgi sahibi olduğu öngörülen üreticilerin seçimine özen gösterilmiştir. Aksi durumda, yapılacak anket çalışmalarından etkili ve amacına uygun cevaplar alınamayacağı öngörülmektedir. Buna yönelik olarak, yukarıda belirtilmiş olan ilçelerde, 50 adet üretici ile anket çalışması yapılmıştır. Anket çalışmaları 2020 yılı TemmuzAğustos aylarında gerçekleştirilmiştir. Bu dönemde yaşanmakta olan korona virüs (Covid-19) salgınından dolayı, arzu edilmiş olmasına rağmen, alınmış olan kısıtlama tedbirlerinden dolayı, daha fazla sayıda üretici ile anket yapma şansı elde edilememiştir. 


\section{Yöntem}

TÜik tarafından oluşturulan 2015=100 bazlı tarımsal girdi fiyat endeksine giren girdi kalemleri ve özellikle gübre ve yem fiyatlarındaki aylık gelişimler detaylı olarak incelenmiştir. KDV istisnası, 2016 yılında yürürlüğe girdiği için, bu istisnanın etkisini daha net ortaya koyabilmek amacıyla, 2016, 2017 ve 2018 yılları değerlendirilmemiştir. Yorumlamalar 2019 ve 2020 yılları için yapılmıştır. Gübre olarak; düz gübreler, bileşik gübreler ve bu ikisinin sentezinden oluşan gübre ve toprak geliştiriciler dikkate alınmıştır. Hayvan yemi olarak; kaba yemler, kesif yemler ve bu ikisinin sentezinden oluşan hayvan yemi fiyat endeksi değerleri esas alınmıştır. Üreticiler ile yapılan anket çalışmasında, üreticilerin KDV istisnasına yönelik algı ve düşüncelerinin olabildiğince objektif olarak belirlenebilmesine yönelik olarak sorular oluşturulmuştur. Anket çalışmasında, üreticiden olabildiğince doğru ve net cevaplar alabilmek için, çoktan seçmeli ve 5'li likert tipi sorular kullanılmıştır: 1: Kesinlikle katılmıyorum, 2: Katılmıyorum, 3: Fikrim yok, 4: Katılıyorum, 5: Kesinlikle katılıyorum. Anket çalışmaları tamamlandıktan sonra, veriler Excel dosyasına aktarılmıştır. Verilerin analizinde esas olarak aritmetik ortalama, standart sapma, yüzde oranları vb. gibi basit tanımlayıcı istatistiklerden yararlanılmıştır.

\section{BULGULAR VE TARTIŞMA}

Gübre ve toprak geliştiriciler, düz gübreler ve bileşik gübrelerde, fiyat endeksi 2019 yılında Ocak ayından Temmuz dönemine gelindiğinde yaklaşık olarak \%7-8'lik bir artış olduğu, buna karşın Aralık ayında bu artışın tamamen ortadan kalktığı tespit edilmiştir. Hayvan yemi, kaba yemler ve kesif yemlerde ise Ocak ayından Aralık ayına kadar olan süreçte, fiyat endeksi değerlerinde yaklaşık olarak \%10'luk bir artış olduğu belirlenmiştir (Çizelge 1). 2020 yılı, OcakEylül döneminde, gübre ve toprak geliştiriciler, düz gübreler ve bileşik gübreler de, Ocak ayından Aralık ayına kadar olan süreçte, fiyat endeksi değerlerinde, önemli artışların olduğu (\%10-12) belirlenmiştir. Aynı dönemde hayvan yemi, kaba yemler ve kesif yemlerde de aynı düzeyli artışların olduğu belirlenmiştir (Çizelge 2). Genel olarak değerlendirildiğinde; gübre ve hayvan yemlerinde KDV istisnası 2016 yılında uygulamaya konulmuştur. TÜik tarafından hazırlanan 2015 yılı baz değerine sahip gübre ve hayvan yemi fiyat endeksi değerlerine göre; genel olarak gübre fiyatlarında 2018 yılı ortasına kadar önemli artışların olmadığı, buna karşın 2018 yılı ortasından sonra, oldukça önemli oranda artışların tahmin edilmektedir. Hayvan yemi fiyat seviyelerinde ise 2016 yılından itibaren 2020 yılına kadar, belirli düzeyde artışların olduğu gözlemlenmiştir. $\mathrm{Bu}$ sebeple, KDV istisnasının hayvan yemi fiyat düzeylerinde önemli etkisinin olmadığı düşünülmektedir. Buna karşın, gübre ve hayvan

Çizelge 1. Gübre ve yem fiyatlarına ilişkin aylık endeks değerleri, 2019

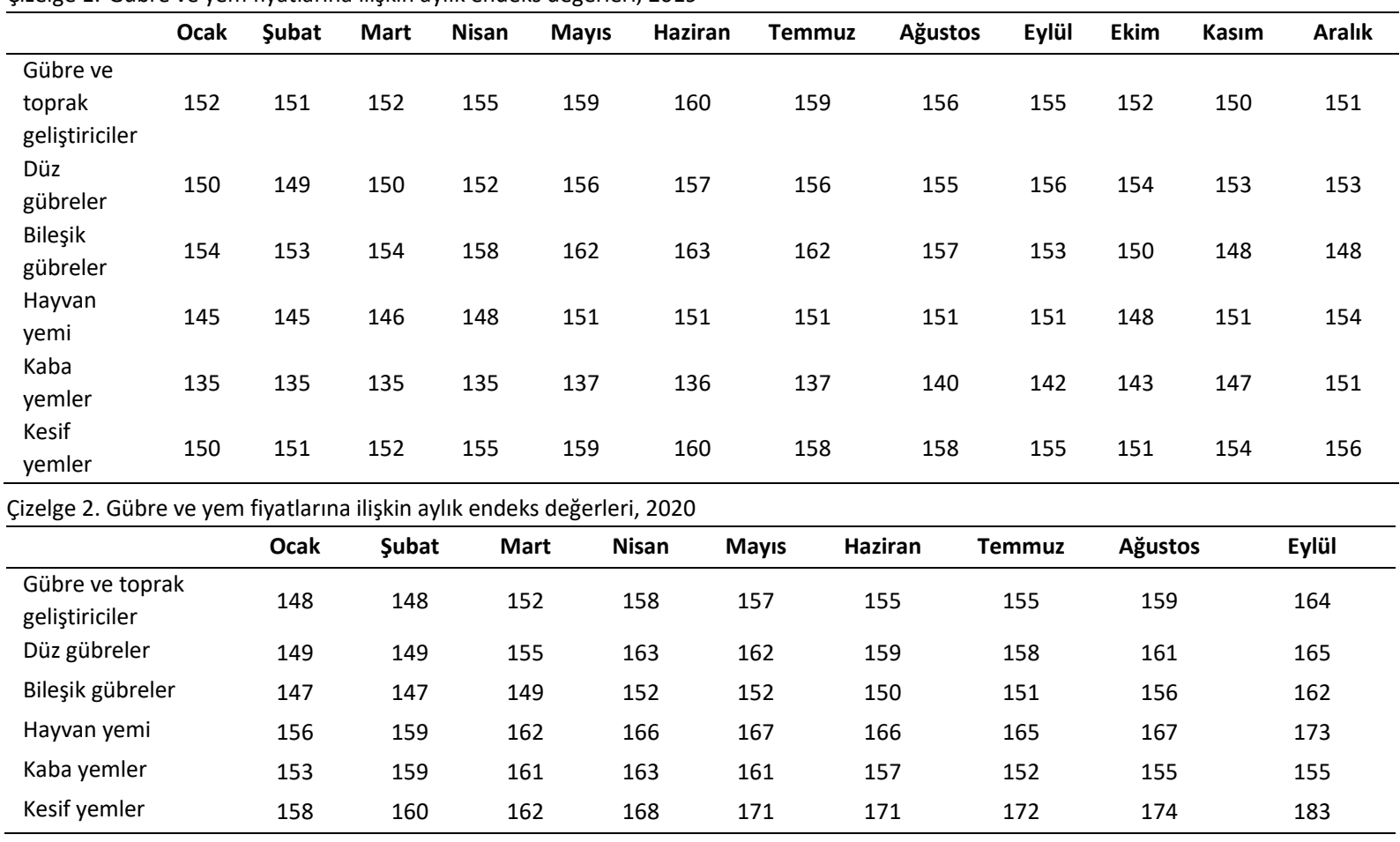


yemi fiyatlar genel düzeyinde, 2020 yılında, 2015 yılı baz olduğu belirlenmiştir. Bu sonuçlardan; 2018 yılı ortasına kadar, her ne kadar diğer faktörlerin de etkisi olduğu öngörülmekle birlikte (gübre üretim durumu, ithalat ve ihracat miktarı, döviz kuru dalgalanmaları vb.), KDV istisnasının, fiyatları aşağı yönlü baskılamak, en azından artmamasını sağlamak açısından önemli faydalarının olduğu dönemine göre \%60-70'lere varan düzeyde önemli artışların olduğu belirlenmiş olmaktadır. Ülkelerin gübre kullanımına yönelik olarak tarımsal desteklemelerin ve diğer birçok politik karar ve faktörün, talep seviyesini arttırdığı, bunun da dünyadaki fiyatlar genel düzeyini etkilediği ifade edilmektedir (Harmanşah, 2018). Dünya geneli gübre fiyatları incelendiğinde ise, bir önceki yıla göre bazı gübre çeşit fiyatlarında artış, bazılarında ise düşüş olduğu belirlenmiştir. 2015 yılındaki \%20 düzeyindeki fiyat artışının, büyük çoğunlukla dolar kurundaki artıştan kaynaklandığı sonucuna varılmıştır. Bu sonuçlar Harmanşah (2019) ile örtüşmekte, Yalçınkaya ve Aktaş'ın (2019) çalışmasındaki kısa dönemdeki yem fiyatlarının döviz kurundan etkilenmesi sonuçları ile uyuşmaktadır.

Üreticilerin yaşlarının 25 ile 80 arasında değiştiği, buna karşın 37-47 ve 48-58 yaş aralığında yoğunlaşmaların olduğu belirlenmiştir. Eğitim durumunda 10 üreticinin ilköğretim mezunu, 21 üreticinin ortaokul, 13 üreticinin lise ve 6 üreticinin de üniversite mezunu olduğu belirlenmiştir. Üretici yaşlarına göre, eğitim düzeyinin değişkenlik gösterdiği, her yaş seviyesinde, farklı eğitim seviyesine sahip üreticilerin olduğu tespit edilmiştir. 5 üreticinin bekar, geriye kalan 45 üreticinin ise evli olduğu belirlenmiştir. Tarımsal işletmelerde; ailedeki birey sayısı 3-4 arasında yoğunlaşma gösterirken, tarımsal üretime katılan birey sayısının ise 2-3 arasında en fazla olduğu tespit edilmiştir. Buna karşın, öğrenci olan ailedeki birey sayısının ise 1-2 arasında değiştiği görülmüştür. Asıl mesleği çiftçilik olan üreticiler ile elde edilen tarımsal ürün brüt geliri analiz edilmiştir. Asıl mesleği çiftçilik olan üreticilerin elde etmiş oldukları yıllık tarımsal ürün gelirinin de göreli olarak daha yüksek olduğu belirlenmiştir. 8 adet üreticinin tarım dışı geliri olduğu tespit edilmiştir. Tarım dışı gelire sahip olan üreticilerin elde etmiş oldukları tarım dışı gelirin de yıllık 18,000 TL ve 60,000 TL arasında değiştiği belirlenmiştir.

Üreticilere, tarımsal üretim faaliyetinde genel olarak kullanmakta oldukları tarımsal girdiler olan; gübre, yem, ilaç, sertifikalı tohumluk ve meyve fidanı, motorin ve elektrikte uygulanan KDV oranı başta olmak üzere diğer vergi oranları hakkında bilgi sahibi olup-olmadıkları sorulmuştur. Böylelikle, bu girdilerde uygulanmakta olan, başta KDV olmak üzere diğer vergiler hakkında da farkındalık düzeyleri belirlenmeye çalışılmıştır. Şu an gübre ve yemde uygulanan KDV istisnası (\%0 KDV) (Tarım ve Orman Bakanlığı tarafından tescil edilmek şartıyla), kimyasal zirai ilaç (\%8), sertifikalı tohumluklar ve meyve fidanı (\%1),
ÇOBANOĞLU F, YILMAZ Hİ, BOZKIRAN S, ÖZTÜRK Y elektrik (\%18) olarak belirlenmekte olup, Anonim (2020) tarafından belirtildiği üzere motorin türleri için, Hazine ve Maliye Bakanlığı tarafından belirlenen Özel Tüketim Vergisi (ÖTV) 2.0559 TL/litre ve KDV oranı \%18'dir. Üreticilerin özellikle gübre, ilaç, motorin ve elektrikte uygulanmakta olan vergi, özellikle KDV oranları hakkında yeterince bilgi düzeyine sahip oldukları belirlenmiştir (Çizelge 3).

Çizelge 3. Üreticilerin tarımsal üretimde kullanılan bazı girdilerde uygulanan KDV oranı hakkında bilgi sahibi olma durumu

\begin{tabular}{lcccc}
\hline \multirow{2}{*}{ Girdiler } & \multicolumn{2}{c}{ Evet } & \multicolumn{2}{c}{ Hayır } \\
\cline { 2 - 5 } & $(\mathrm{n})$ & $(\%)$ & $(\mathrm{n})$ & $(\%)$ \\
\hline Gübre & 47 & 94 & 3 & 6 \\
Yem & 10 & 20 & 40 & 80 \\
Illaç & 47 & 94 & 3 & 6 \\
Sertifikalı tohumluk ve & 19 & 38 & 31 & 62 \\
$\begin{array}{l}\text { meyve fidanı } \\
\text { Motorin }\end{array}$ & 40 & 80 & 10 & 20 \\
Elektrik & 40 & 80 & 10 & 20 \\
\hline
\end{tabular}

Çalışmanın bu aşamasında ise üreticilerin bazı tarımsal girdilerdeki (gübre ve yem) KDV istisnasına ilişkin ifadelere katılım düzeyleri likert ölçeği ile belirlenmiş olup, bu skorlara ait ortalama ve standart sapma değerleri belirtilmiştir (Çizelge 4).

Üreticilerin; "Küçük ölçekli işletmelerde, büyük ölçekli işletmelere göre kullanılan diğer tarımsal girdilerde de KDV istinası uygulaması, kademeli olarak genişletilebilir.", "Kullanılan girdi miktarı ile elde edilen ürün kalitesi arasındaki ilişkiyi geliştirecek destek mekanizmaları oluşturulabilir.", ifadelerine katılım düzeyinin oldukça yüksek olduğu belirlenmiştir. Buna karşın, "Girdi kullanımında, tavsiye aldığım birimler (ilaç-gübre bayileri, Tarım Kredi Kooperatifleri, Tarım İl-illçe Müdürlükleri vb.) arasında işbirliği olanakları artmıştır.", "Diğer girdilerin kullanımında olumlu etki yapmıştır.", "Bu destek tutarları, üreticilerin kullandıkları girdi miktarlarına paralel olarak doğrudan üreticiye nakit destek olarak verilmesi daha uygun olabilir." ve "Tarım ve Orman Bakanlığı onaylı olmayan gübre ve yem girdilerine de destek verilmesi isabetli olabilir." ifadelerine katılım düzeyinin en düşük olduğu belirlenmiştir.

\section{SONUÇ}

$\mathrm{Bu}$ çalışma ile gübre ve yem fiyatlarındaki değişimleri belirleyen ve özellikle söz konusu girdilerdeki KDV istisnasının üreticiler açısından değerlendirilmesi ortaya konulmuştur. Genel olarak değerlendirildiğinde; 2018 yılı ortasından itibaren, gübre fiyatları genel düzeyinde önemli artışların olduğu belirlenmiştir. Hayvan yemi fiyat düzeylerinde ise 2016 yılından itibaren, belirli düzeyde artışların olduğu gözlenmiştir. Bu sebeple, KDV istisnasının hayvan yemi fiyat düzeylerinde önemli etkisinin olmadığı düşünülmektedir. Buna karşın, gübre ve hayvan yemi 
Çizelge 4. Üreticilerin gübre ve yemde uygulanmakta olan KDV istisnasına ilişkin bazı ifadelere katılım düzeyi

\begin{tabular}{|c|c|c|}
\hline ifadeler & Ortalama & Std Sapma \\
\hline Maliyetlerin azaltılmasında olumlu etkisi var. & 3.58 & 1.20 \\
\hline Girdi satın alma kararlarında kolaylık sağlamıştır. & 3.22 & 1.07 \\
\hline Diğer girdilerin kullanımında olumlu etki yapmıştır. & 2.94 & 1.08 \\
\hline $\begin{array}{l}\text { Tarım ve Orman Bakanlığı onaylı gübre ve yem girdilerine destek verilmesi isabetli } \\
\text { olmuştur. }\end{array}$ & 3.56 & 1.43 \\
\hline Teknoloji kullanımına (damla sulama vb.) olumlu etki yapmıştır. & 3.40 & 1.14 \\
\hline $\begin{array}{l}\text { Girdi kullanımında, tavsiye aldığım birimler (ilaç-gübre bayileri, Tarım Kredi } \\
\text { Kooperatifleri, Tarım III-illçe Müdürlükleri vb.) arasında işbirliği olanakları artmıştır. }\end{array}$ & 2.90 & 1.52 \\
\hline Söz konusu desteği hiç fark etmedim. & 3.24 & 1.32 \\
\hline $\begin{array}{l}\text { Bu destek tutarları, üreticilerin kullandıkları girdi miktarlarına paralel olarak doğrudan } \\
\text { üreticiye nakit destek olarak verilmesi daha uygun olabilir. }\end{array}$ & 2.96 & 1.44 \\
\hline $\begin{array}{l}\text { Tarım ve Orman Bakanlığı onaylı olmayan gübre ve yem girdilerine de destek verilmesi } \\
\text { isabetli olabilir. }\end{array}$ & 2.98 & 1.39 \\
\hline Kullanılan diğer tarımsal girdilerde de KDV istinası uygulaması genişletilebilir. & 3.56 & 1.18 \\
\hline $\begin{array}{l}\text { Küçük ölçekli işletmelerde, büyük ölçekli işletmelere göre kullanılan diğer tarımsal } \\
\text { girdilerde de KDV istinası uygulaması, kademeli olarak genişletilebilir. }\end{array}$ & 4.34 & 0.92 \\
\hline $\begin{array}{l}\text { Kullanılan girdi miktarı ile elde edilen ürün kalitesi arasındaki ilişkiyi geliştirecek destek } \\
\text { mekanizmaları oluşturulabilir. }\end{array}$ & 4.10 & 0.95 \\
\hline
\end{tabular}

fiyatlar genel düzeyinde, 2020 yılında, 2015 yılı baz dönemine göre \%60-70'lere varan düzeyde önemli artışların olduğu belirlenmiştir. 2015 yılında, yılbaşından yılsonuna kadar olan süreçte dolar kurunda \%24,4'lük bir artış olduğu tespit edilmiştir. Dünya geneli gübre fiyatları incelendiğinde ise, bir önceki yıla göre bazı gübre çeşit fiyatlarında artış, bazılarında ise düşüş olduğu belirlenmiştir. 2015 yılındaki \%20 düzeyindeki fiyat artışının, büyük çoğunlukla dolar kurundaki artıştan kaynaklandığı sonucuna varılmıştır.

Üreticilerin özellikle gübre, ilaç, motorin ve elektrikte uygulanmakta olan vergi, özellikle KDV oranları hakkında yeterince bilgi düzeyine sahip oldukları belirlenmiştir. Üreticiler üretim maliyetlerini düşürerek gıda enflasyonu ile mücadeleye yardımcı olabileceklerdir. Ancak enflasyon ile mücadelede üreticinin eline geçen fiyatlar yerine, üretim maliyetlerini düşürmeye yönelik önlemlerin alınması gerekmektedir. Tarımsal girdi fiyatlarının izlenmesi, değerlendirilmesi ve müdahalesi için Gıda ve Tarımsal Ürün Piyasaları İzleme ve Değerlendirme Komitesi'nin yetkilendirilmesi ve diğer ilgili kamu kurum ve kuruluşları (Tarım ve Orman Bakanlığı, Rekabet Kurumu vd.) ile gerekli protokollerin sağlanması gerekmektedir.

Enflasyonla mücadele için yapılmakta olan girdi desteklemelerinin etkilerinin; sürdürülebilirlik (ekonomik, çevresel ve sosyal) boyutunda araştırılması gerekmektedir.

Tarımsal girdileri kapsayan işletme kredilerinin finansmanında, üreticilere daha uzun vadeli ödeme planlarının oluşturulmasının, özellikle yaşanmakta olan üretim döneminde (Covid-19 salgın dönemi) önemli olduğu düşünülmektedir.

Hayvancılıkla uğraşan üreticilerin kredi teminatı olarak hayvan varlığını göstermesi, başka teminat gösteremeyecek olan üreticilerin, sistem dışı kaynaklardan, yüksek oranlarla borçlanarak üretim maliyetlerini arttırmaktadır. Bankaların hayvan varlığını teminat olarak kabul etmesinin, Hazine ve Maliye Bakanlığı tarafından sağlanması gerektiği tavsiye edilmektedir. Özellikle söz konusu teminat kabul edilirse, girdi kullanım miktar ve etkinliğinin artabileceği öngörülmektedir.

Kooperatiflerin, tarımsal ürünlerin üretimi ve pazarlaması açısından önemli bir göreve ve avantaja sahiptir. Ülkemizde, tarım sektöründe faaliyet gösteren kooperatiflerin, özellikle çalışmanın konusu olan tarımsal girdi temini ve pazarlamasında göreli olarak önemli çalışmalarının olduğu belirtilmelidir. Buna karşın, söz konusu potansiyel ve etkinliğin yetersiz olduğu ifade edilebilir. Buna yönelik olarak tüm paydaşlar arasında etkin bir işbirliğinin geliştirilmesinin önemli olduğu düşünülmektedir. Buna yönelik olarak Donat (2021) tarafından dramatik bir çözüm sunulmuştur. Bu amaçla, kooperatifçiliğin geliştirilmesine yönelik olarak Tarım Bakanlığı ve Ticaret Bakanlığı eşgüdümünde, ilgili sivil toplum kuruluşlarının da katılımı ile tarımsal kooperatiflerin kuruluş, yönetim ve faaliyetleri ile ilgili kanunu yeniden düzenleyerek, yöneticilerine mutlaka tüm şahsi varlıklarıyla sorumluluk getirilmesi önerilmiştir. 
Türkiye'de Tarım Kredi Kooperatifleri, özellikle tarımsal girdilerin temininde, halen oldukça önemli bir paya sahiptir. Ancak girdi maliyetlerinin düşürülmesinde etkinliğinin biraz daha arttırılabileceği düşünülmektedir.

Sonuç olarak, en önemli tarımsal girdiler olan gübre ve yemde 2016 yılında yürürlüğe girmiş olan KDV istisnasının, özellikle fiyatların düşmesi yönünde belirli düzeyde etkisinin olduğu, ancak bu etkinin çok kısa sürede ortadan kalktığı düşünülmektedir. Üreticilerin de, söz konusu etkiyi, gübre ve yemlerin piyasa fiyatlarında çok düşük azalma olarak gözlemledikleri belirlenmiştir. Bunun da, gübre ve yem hammaddelerinin büyük oranda ithalat ile karşılanmasına dayandırılabileceği sonucuna varılmaktadır. İthalat söz konusu olunca da, döviz kurundaki dalgalanmalar etkisini göstermektedir. Özellikle tüm dünya genelinde olduğu gibi, Türkiye'de de, 2018 yılı ortalarından itibaren döviz kurlarında önemli artışların olduğu ifade edilebilir. Bunun yansıması olarak, tarımsal girdi fiyatlarında önemli artışların olduğu, bu artış oranlarının da KDV istisnasından kaynaklanan indirimin piyasalardaki etkisini baskıladığı ve/veya ortadan kaldırdığı düşünülmektedir.

\section{KAYNAKLAR}

Anonim (2016) Tarım Kredi, Ocak 2016, 33 (522): 12-13.

Anonim (2018a) Uluslararası Gübre Sanayi Birliği (IFA), Fertilizer Consumption Reports. www.ifastat.org (Erişim Tarihi: 27/05/2021).

Anonim (2018b) Tarımsal Araştırmalardan Görünüm. TAGEM Ar-Ge İnovasyon,

Tarımsal Araştırmalar ve Politikalar Genel Müdürlüğü. T.C. Gıda, Tarım ve Hayvancılık Bakanlığı.

Anonim (2018c) Gübre Sektör Politika Belgesi 2018-2022. TAGEM, Tarımsal Araştırmalar ve Politikalar Genel Müdürlüğü. T.C. Gıda, Tarım ve Hayvancılık Bakanlığı, Ankara.

Anonim (2020) Petrol ve LPG Piyasası Fiyatlandırma Raporu. Ağustos 2020. Enerji Piyasası Düzenleme Kurulu.

Anonim (2021) Food and Agriculture Organization of the United Nations. www.fao.org/faostat/en/?\#data/RA (Erişim Tarihi: 26/05/2021).

Akbay KC, Ak i (2018) Karma Yem Teknolojisindeki Gelişmelerin Karma Yem Kalitesine ve Yem Değerine Etkileri. Bursa Uludağ Üniversitesi Ziraat Fakültesi Dergisi, 32(2) : 175-188.
ÇOBANOĞLU F, YILMAZ HI, BOZKIRAN S, ÖZTÜRK Y

Bayramoğlu Z, Karakayacı Z, Ağızan K, Ağızan S, Bozdemir, M (2021). Başlıca Sebze Ürünlerinde Üretim Maliyetlerini Etkileyen Faktörlerin Belirlenmesi. Kahramanmaraş Sütçü İmam Üniversitesi Tarım ve Doğa Dergisi, 24(3) : 603-613.

Demir F (2016) Son Düzenlemeler Çerçevesinde Tarım ve Hayvancılık Sektöründe KDV İadesi. Vergi Sorunları Dergisi, Haziran 2016, 333: 135-141.

Donat i (2021) Adana Çiftçiler Birliği bilgi notu. https://www.bloomberght.com/yorum/irfandonat/2271849-25-maddede-ciftcinin-2021-beklentisi (Erişim Tarihi: 04/01/2021).

Harmanşah F (2018) Gübre sektöründe neler oluyor? TÜRKTOB Dergisi 17: 42-45.

Harmanşah F (2019) Tarımsal üretimin önemli bir girdisi: Gübre. TÜRKTOB Dergisi, 30: 20-29.

Gezgin Ş (2015) Türkiye'de Gübre Üretim ve Tüketimi, Dengeli Gübreleme. Türkiye Ziraat Mühendisliği VIII. Teknik Kongresi, 12-16 Ocak 2015, Ankara, 10111028.

Ilgar R (2020) Gübreler ve Çanakkale'deki Kullanımı. Avrasya Sosyal ve Ekonomi Araştırmaları Dergisi, 7(12) : 1-16.

Kara H, Eroğlu A (2018) Tam Sayılı Doğrusal Programlama Metodu İle Entansif Hayvancılık İşletmesinin Kapasite Planlaması: Konya (Ereğli) Örneği. Çukurova Tarım ve Gıda Bilimleri Dergisi, 33(2) : 31-46.

Sıkar B, Çimrin T (2020) Hatay İlinde Karma Yem ve Hammadde İşletmelerinin Sosyo-Demografik Yapısı. Kahramanmaraş Sütçü İmam Üniversitesi Tarım ve Doğa Dergisi, 23(4) : 1096-1105.

Şahin, G (2016) Türkiye'de Gübre Kullanım Durumu ve Gübreleme Konusunda Yaşanan Problemler. Tarım Ekonomisi Dergisi, 22(1) : 19-32.

Şekerdil I, Engindeniz S (2020) İnek Sütü Üretiminde Maliyet Analizi: İzmir'in Foça illçesi Örneği. Hayvansal Üretim Dergisi, 61(1) : 41-48.

Tüik (2020) 2015=100 Bazlı Tarımsal Girdi Fiyat Endeksi. Türkiye İstatistik Kurumu, Ankara.

Ural A, Kılıç i (2011) Bilimsel Araştırma Süreci ve SPSS ile Veri Analizi. Detay Yayıncılık, Ankara.

Yalçınkaya HS, Aktaş MA (2019) Yem Üzerindeki KDV Oran İndirimlerinin Et ve Süt Fiyatlarına Etkisi. Marmara Üniversitesi Öneri Dergisi 14(51): 38-60. 
